\title{
Discourses of transnational feminism in Marie du Toit's Vrou en feminist (1921)
}

In this article I investigate transtextuality in Vrou en feminist (Woman and Feminist, 1921) by Marie du Toit in order to demonstrate how she grafted first-wave transnational feminism onto the Afrikaans context. Du Toit's book is approached as a space of contact between progressive European and North American thought and a South African, particularly Afrikaner, mindset. Du Toit relied on a multiplicity of late nineteenth and early twentieth centuries discourses to support her argument that Afrikaner women become part of the feminist movement. Due to the numerous quotations from scientific papers and literary fiction, mostly English but also Dutch, her book can be described as a heteroglot text. Utilizing the histoire croisée approach, I discuss Du Toit's text on the macro and micro scale: I locate it in a historical perspective as a literary document and focus on the ways in which diverse voices intersect and converse with one another. I argue that the book was an unsuccessful attempt at inviting the Afrikaans reader into a transnational imagined community of suffragettes because of prejudice against the English language and culture. English sources, which Du Toit extensively quoted, deterred potential Afrikaans supporters, and consequently prevented transfer of feminist thought. Even though she also supported her views with some texts in Dutch in wanting to appeal to her reader's associations with a more familiar Dutch culture, this tactic was insufficient to tip the balance. Keywords: cultural mobility, first-wave feminism, heteroglossia, hybridity, intertextuality, Marie du Toit, transtextuality.

\section{Introduction}

South African white women were granted suffrage in 1930. Until the 1990s, social historians claimed that only the English-speaking part of South African society was receptive to the ideas of first-wave feminism (Vincent 1-2). This movement, which originated in Europe and in the United States in the late nineteenth century, fought for the acknowledgement of women's presence and agency in the public sphere. Its goals included granting women political rights by means of suffrage, but also providing both sexes with equal access to all forms of education and professional careers and raising women's awareness of their reproductive health. Afrikaners-both women and men-perceived it as an unwanted English influence and a foreign threat to social order, this aversion being a result of the Anglo-Boer War (1899-1902). The claim about Afrikaner women's disinterested stance on women's suffrage has, however, been revised. Lou-Marie Kruger (183-4), Marijke du Toit (214-5, 317), and Louise Vincent (10-2) accentuate that even though these women did not subscribe to the English-speaking campaign, they did advocate the right to vote- but within a different rhetoric. Afrikaans-speaking women's emancipation served a nationalist design aiming to increase the number of white voters. Consequently, it can be concluded that transnational feminism did not manage to offer a shared identity to all white South African women.

Yet, South Africa did produce such feminist writers as Olive Schreiner (1855-1920) and lesser-known Marie du Toit (1880-1931), whose texts subscribed to the transnational character of the feminist movement and were an attempt to introduce white South African women to an imagined community of suffragettes. Benedict Anderson proposes that, in a sense, this imagined community was formed thanks to circulating printed texts.

Anderson argues that Luther's translation of the Bible was the first highly influential best-seller (39) and later on the novel (25-6) and the newspaper (33-5) played a crucial role in shaping communities consisting of readers who, although they never had a chance to meet in person, were connected by a shared worldview communicated by texts. Although this concept initially served to explain a nation-forming mechanism, it is also applicable to other, transnational formations (Venuti 482) - a community of feminist readers being one of them.

Małgorzata Drwal is assistant professor at the Department of Dutch and South African Studies, Faculty of English, Adam Mickiewicz University in Poznan, Poland.

Email: mdrwal@wa.amu.edu.pl

(D) https://orcid.org/0000-0003-4871-1170

D0l: https://doi.org/10.17159/tl.v57i2.7765

DATES:

Submitted: 31 December 2019; Accepted: 26 March 2020 Published: .22 July 2020 
Olive Schreiner's Woman and Labour (1911) formed the most influential theoretical contribution by a South African author to early feminism. Recognized by the Afrikaans and English press, this book, however, had a far-reaching impact on feminism outside South Africa. It was translated into a number of languages. The English feminist Vera Brittain in her Testament of Youth (1933) referred to it as the "bible' of the feminist and suffrage movements" (28); the Dutch feminist press described Schreiner as:

een vrouw met helderen blik, die de dingen overziet in hun geheel, niet de wereld afmeet naar het kringetje, dat om haar cirkelt.

a woman with a clear vision, who sees things in their entirety, does not measure the world according to the little circle around her. (Anon, "De vrouw en arbeid" 29, my translation)

Ten years after Schreiner's English publication, Du Toit wrote its Afrikaans counterpart Vrouenfeminist [sic]. Ofiets oor die vrouevraagstuk (1921) (Woman and Feminist. Or Something about the Woman Question). Both books advocated not only women's suffrage but also women's economic independence, equal remuneration for equal work that women and men do, and equal access to all kinds of education and professions. They presented all the goals the first-wave feminist movement strove for. When Schreiner published her book, she already was a recognized author, but Du Toit was—and has remained until today - a rather obscure figure. Despite Du Toit's book being published by the nationwide publisher Nasionale Pers, it did not attract a wide readership. The more conservative voices of M. E. Rothmann and Mabel Malherbe were those that came to be identified with the Afrikaner women's political emancipation in the 1920s (Marijke du Toit 209-10).

Until today there has been relatively little scholarly interest devoted to Du Toit and her Vrou en feminist. Brink (281) and Pretorius (9-10) merely acknowledge that the book was a marginal, lonely voice, unrecognized due to its critical attitude towards the idealized image of Afrikaner femininity, the volksmoeder. As an object of a more detailed inquiry, the book first drew the attention of theologians: Landman points out that Du Toit presented ideas that were exceptionally progressive for her Calvinist milieu (339). More recent discussions of the text as a literary document have, however, not been comprehensive enough. They only signal the existence of the text rather than provide an in-depth analysis or explore its content. The most extensive gesture of attention to Vrou en feminist is a ten-page long chapter containing a discussion of her text and a couple of shorter excerpts from it in an anthology of South African women writers compiled by Pieta van Beek and Annemarié van Niekerk (533-42).

Du Toit's book is remarkable for a couple of reasons. Firstly, because it constitutes an entry of the Afrikaans language into a transnational feminist discourse. Secondly, because of its encyclopaedic character and syncretic, intertextual content: Du Toit refers to a large number of very diverse sources, mostly in English but also in Dutch. Consequently, the book is a product of cultural mobility (Greenblatt 250-3) of European and North American texts to South Africa. ${ }^{1}$ In this respect texts are understood both as material objects-books-but also as modes of thinking and kinds of discourse with their vocabulary and rhetorical devices.

In this article, I present Vrou en feminist as a space of contact at an intersection of discourses transmitting progressive European and North American thought and a South African - in particular Afrikaner-mindset, utilizing the histoire croisée method. As part of transfer studies, this approach explores "connected and shared" (Werner and Zimmermann 31) aspects of history. Focusing on intersections of contexts, discourses, cultures, and concepts (31), it invites looking at the object of inquiry from the macro and micro perspectives (42). Applying the first one, I locate the text as a literary document functioning in a historical social context. The latter, employing Mikhail Bakhtin's concepts of heteroglossia (Bakhtin 324-6) and hybridity of an utterance (358), allows me to focus on its content where diverse voices intersect and converse with one another.

In this article, I start with a brief presentation of how Du Toit positioned herself as an author. After that, I introduce the concepts of transtextuality, heteroglossia, and hybridity. Then, by analysing transtextual references and discourses on which Du Toit relied in order to legitimate her views, I situate Vrou en feminist against a transnational background, demonstrating how it engages in a debate about local and global issues. Finally, I analyse press reviews of the book. Pointing to the Boer-Brit resentment, I set out to answer the question of why Du Toit's propositions attracted so little interest and failed to draw Afrikaans women into an imagined community of suffragettes. 


\section{Marie du Toit as an author}

Biographical information about Du Toit is scant. Maria Magdalena du Toit was born in 1880 in Paarl and died of tuberculosis in 1931 in Potchefstroom, in the house of her famous brother (Jacob Daniël, known as Totius) where she, an unmarried teacher, lived (Van Beek and Van Niekerk 536). She must have been a rebel, considering the profiles of her brother, a well-known poet, who expressed the conservative Calvinist spirit in his work, and her father S. J. du Toit, a prominent activist that advocated for the Bible to be translated into Afrikaans. In the foreword to her book, she modestly excuses her attempt at writing, a task for "n ander geleerde en knappe Afrikaanse dame" (some other learned and capable Afrikaans lady). Claiming that she is not competent enough to expertly present the women's movement's goals to the Afrikaans reader, she argues that she felt compelled to take up the challenge nevertheless, because:

daar [het] bykans nooit in Afrikaans'n woord ter ere of ter gunste van'n vrou verskyn nie en wel heel wat van die teenoorgestelde.

there has virtually never appeared a word in Afrikaans in honour or in favour of a woman and a lot of the opposite.

Despite this excuse, she goes on to demonstrate an impressive erudition, giving a broad picture of diverse aspects of international feminism, supporting her arguments with references to numerous sources. She undertakes to mediate not only between the perspectives of two sexes but also between two cultures: those of the English and the Afrikaner. Her book appeared in 1921 when, in the wake of the Anglo-Boer War (1899-1902), anti-British sentiment was still rife. The resentment was due to the memory of British aggression, aggravated by subsequent reconstruction policy conducted by Alfred Milner, Governor of the Transvaal and Orange River Colony (1902-1905). Anglicization of administration and diminishing the significance of Dutch at the cost of English as the language of instruction in schools (Swart and Van der Watt 134-5) were seen as yet another act of violence against Afrikaners.

Therefore, Du Toit wishes to further the efforts of Olive Schreiner who strove not only for female emancipation but also for a better understanding and reconciliation between the British and the Boer. On a number of occasions in the book, Du Toit expresses her admiration for Schreiner and regrets that neither Dutch-Afrikaans press nor Afrikaans women appreciated Schreiner's merits as an outstanding thinker and a mediator between the British and the Boers during the Anglo-Boer War (155).

\section{Transtextuality, heteroglossia, and hybridity}

One of the most prominent features of Vrou en feminist is its transtextuality, which Genette defines as "the textual transcendence of the text" (Palimpsests: Literature in the Second Degree 1), including all manners, both conspicuous and latent, in which one text is related to other texts (1). Using transtextuality as an umbrella term, he introduces a systematic sub-classification of interconnections between texts, drawing attention to different ways in which each of them affects the reader. Thus, transtextuality encompasses intertextuality, paratextuality, metatextuality, and architextuality, among others. ${ }^{2}$ As Genette argues, intertextuality involves "the actual presence of one text within another" (2). Intertextuality includes acknowledged borrowings, such as quoting, but also unacknowledged ones, such as plagiarism, and more subtle or covert references, such as allusion. Paratexts are the "thresholds" (Genette, Paratexts. Thresholds of Interpretation 2) that the reader has to pass to enter the text. These are such elements adjacent to it as the title, prefaces, epigraphs, footnotes, illustrations (peritext), but also all pieces of biographical data about the author, interviews, correspondence, and reviews (epitext) (5). Metatextuality denotes commentaries on other texts, and architextuality describes a generic relationship between texts (Palimpsests 2-4). While metatextuality is a critical relationship between texts, which presents the reader with a voiced opinion, architextuality is a "completely silent" (4) mechanism which addresses the reader's familiarity with the codes employed by diverse genres, and thus markedly determines the reader's expectations and reception of the text (5).

Transtextuality is related to heteroglossia (in Russian raznorečie, which can be translated as "varied-speechedness"), which is the key concept in Bakhtin's discussion of the nature of language. It is a quality describing every single language as consisting of a multitude of languages, each of which is always "ideologically saturated" (271). By this he means that language contains "forms for conceptualizing the world in words, specific world views, each characterized by its own objects, meanings and values" (292), which can be interrelated, contradictory, or supplementary to one another. 
Heteroglossia allows for the creation of hybrid utterances which are, according to Bakhtin, "a mixture of two social languages" (358). The language of the novel is an intentional hybrid of two individualized "language-intentions": that of the author and of the character that the author employs to speak. Although Bakhtin focuses on the novel's "dialogic word", his point of departure is an observation that every utterance, not only novelistic prose, "partakes of social and historical heteroglossia" (272).

The abundance of references to foreign sources in Vrou en feminist - ranging from popular Dutch and English novels to theoretical publications on the history of female emancipation in Europe-testifies to the circulation of thought and texts between Europe and South Africa. Du Toit was also by no means a passive recipient. On the contrary, addressing a wide range of topics, from theology to fashion, her book catalogues issues with which first-wave feminism was concerned and situates them in the local South African context. The result is a hybrid text, rhetorical and polemical (see Bakhtin 353-4), creatively incorporating borrowings from other contexts. As Bakhtin argues, hybridity entails merging "two speech manners, two styles, [...] two semantic and axiological belief systems" (304), therefore rhetorical genres, so eagerly employing hybridity, are "intensely dialogized forms" that serve "the double-voiced rhetorical transmission of another's word" (354). Du Toit makes use of this feature in her persuasive prose where various voices speak from inserted translated excerpts, paratexts, and other transtextual references.

The resultant heteroglossia provides the text's architextuality, as it involves a range of professionally specific languages: the language of the fiction writer, the scholar, the feminist theoretician, the journalist. All of these languages import their respective genres with their dictions (see Bakhtin 288-9), both artistic-introduced by means of excerpts from novels - and non-artistic, by means of quotes from press and from scientific, theological, sociological, historical, and biographical writings.

A hybrid text possesses yet another quality: it can subvert existing order and threaten the centre of cultural power (Bakhtin 368-70) by appropriating existing discourses to its own ends. While Du Toit lists science-based facts or resorts to the discourse of theological treatise to legitimate her argument, she engages in discussion playing by the rules set by dominant-both progressive and conservative-discourses. But she adopts them all to refute charges levelled at feminism by conservative voices in South Africa and presents a subversive alternative.

\section{Paratextuality: Reading lists and epigraphs}

Addressing the Afrikaans middle-class reader, Du Toit's Vrou en feminist speaks in the persuasive voice of a wellread intellectual who, in a systematic and disciplined way, argues for an unpopular view. To back her views, she invites voices representing the discourses that were dominant in the late nineteenth and early twentieth centuries-she is interpreting and providing emphasis to some, while polemicizing with others, criticizing or even ridiculing them, creating a heteroglot text (see Bakhtin 353).

Paratexts are the most conspicuous forms of referencing other sources. In Du Toit's book they include a list of consulted and recommended literature and epigraphs that precede chapters. The list contains publications on the history of feminism in Europe: Feminism in Germany and Scandinavia (1915) by Katherine Anthony; The Women's Victory and After (1920) by the English feminist Millicent Garrett Fawcett; Way Stations (1913), a collection of essays about suffrage struggle by the American suffragette Elizabeth Robins; and a South African take on the women's emancipation issue - Olive Schreiner's Woman and Labour (1911). Other books that are mentioned discuss the presence of women in the medical profession (English Medical Women by A. H. Bennett, 1915) and their roles during the war (Women War Workers, edited by Gilbert Stone, 1917 and Women and Soldiers by Alec-Tweedie, 1918), or offer an anthropological perspective, like Problems of the Sexes (1913) by Jean Finot.

Next to theoretical writings, the list also contains belletristic ones, all offering progressive role models, such as the novel The Convert (1907) by Elizabeth Robbins, with a suffragette as a protagonist, and Elisabeth Davenay (1909) by Claire de Pratz, presenting a young, educated and independent woman. Furthermore, every chapter is interspersed with more recommendations or criticism. For example, Du Toit praises Mary Wollstonecraft's The Vindication of the Rights of Women (1792), one of the founding texts of feminism, describing it as "een van die moedigste ondernemings van die wêreld" (one of the bravest endeavours of the world) (110). Among the works that she criticizes 
is Jean Jacques Rousseau's Emile, or on Education (1762). Du Toit argues that the character of Sophie, allegedly the ideal woman, is presented in such a way that:

geen vrou, as sy waarlik selfrespek het, die beskrywing kan lees sonder dat die bloed van verontwaardiging haar na die gesig styg.

no woman, if she really has some self-respect, can read this description without the blood of indignation raising to her face. (11l)

Most of the recommended literature is publications in English, including texts that Du Toit read in English translation. Worth mentioning, however, is a Dutch text by Henriëtte Roland Holst. De maatschappelijke ontwikkeling en de bevrijding der vrouw (The Social Development and the Liberation of the Woman, 1914) gives a glimpse of the discussion between European feminists and socialists and positions the issue of women's emancipation against society's class structure. Since the white working class was a new social formation in South Africa that had only begun to take shape in the 1920s (Berger 90), including this text in the reading list indicated that Du Toit anticipated social change.

Another sort of paratext is the epigraphs that precede each of the eleven chapters. These are usually English or Dutch excerpts coming from diverse sources ranging from novels to the Bible. This syncretism is characteristic for the whole of Du Toit's argument. She can seamlessly move between the discourse of literature and the discourses of natural sciences or theology to illustrate the same point. For example, the first chapter entitled "Misverstand" (Misunderstanding), in which Du Toit elaborates on why women's position is inferior to men, is preceded by a quote from an English translation of Jean Finot's anthropological work Problems of the Sexes: "By believing themselves of unequal importance, the two sexes have erected between themselves, for centuries, barriers of falsehood" (9). In turn, the chapter "Klere-klagte" (Clothes complaints), in which she discusses how clothes have hampered female health and freedom of movement, is preceded by a quote from the Dutch novel Majoor Frans (1875) by Geertruida Bosboom-Toussaint:

Ik weet heel goed [...] dat ze mij overal aangapen als een kermiswonder, omdat ik de vrijheid neem mij te kleden naar mijn conveniëntie, en niet naar hun smaak.

I know very well [...] that everywhere they stare at me as if I was a country fair curiosity, because I take the liberty to dress conveniently and not according to their taste. (93)

Before the chapter "Huwelik en huislike lewe" (Marriage and home life) come two mottos: an English and a Dutch one, with which $\mathrm{Du}$ Toit seems to demonstrate that the same message comes from both language traditions. A stanza is taken from a poem by the American poet and politician Thomas Dunn English (1819-1902):

Women are timid, cower and shrink

At show of danger, some folk think;

[...] And, gentle is their manner, they

Do bold things in a quiet way. ${ }^{3}$

This echoes a passage from the Bible, the Statenvertaling, a text that was important and familiar to the Calvinist reader:

Zij doet haren mond open met wijsheid, en op hare tong is leer der goeddadigheid. (Spr. 31:26)

She openeth her mouth with wisdom; and in her tongue [is] the law of kindness. (Proverbs 31:26, English version after King James Bible)

\section{References to prose fiction}

Offering a reading list of progressive literature in English and Dutch and referring to external sources throughout the book, Du Toit engages in an awareness-raising campaign through reading. She states her desire:

Ek wou dat ek de 'talen der menschen en der engelen' magtig was om my sekse te beweeg meer tyd en geld te bestee aan lees en leesstof; te lees wat leersaam, diep en opvoedkundig is.

I wish that I spoke 'the languages of humans and angels' to inspire my sex to spend more time and money on reading and literature; in order to read what is informative, deep and pedagogic. (31) 
Since reading grants an access to a broader perspective, Du Toit wishes her readers would transcend the parochial view so that they can see "waar ons staan in vergelyking met andere landen" (where we stand in comparison with other countries) (32). In this way, she declares her striving that Afrikaner women be included into the transnational imagined community of modern women aware of their social and political position.

She observes, moreover, that women all too often waste their time and mental capabilities either on unnecessary handiwork or on reading only light recreational content. Taking a keen interest in social and political life would be beneficial for their mental faculties as it is "oefening vir haar brein" (exercise for her brain) (120). Therefore, Du Toit carefully chooses instructive texts for her readers as she believes that literature "gee 'n goeie kykie in'n vrouehart" (gives a good insight in a woman's heart) (73), and, furthermore, is an effective medium of presenting situations and characters with which the reader can identify. For example, she praises Olive Schreiner for the accuracy with which she depicted women's position in her "almost prophetic" ("haas profeties(e)") (155) allegory "Three Dreams in the Desert" (1890).

Unlike Olive Schreiner, Du Toit was not a professional writer. Therefore, to support her view that Afrikaner women need feminism, she included other authors' voices - voices expressing their intention "in a refracted way" (Bakhtin 324) through characters' words. Thus she introduces into her argument the "double-voiced, internally dialogized discourse" (324) of the European novel, quoting the Dutch A. G. L. Bosboom-Toussaint's Majoor Frans (75, 79-80, 93), Everhardus Johannes Potgieter's Marie (1864) (71), or the English George Meredith's Diana of the Crossway (1885) (76-8), to name just a few examples. The references to Dutch fiction in Du Toit's argumentation can be interpreted as an attempt to underline the affinity of the Afrikaner middle-class to the Dutch cultural centre, especially to its common-sense mentality. Majoor Frans serves to introduce a new model of womanhood: Frans, the protagonist, emanates strength and resolve in her down-to-earth approach to life. This quintessentially unconventional and independent heroine manifests her freedom not only by the choice of the clothes she wears but also by openly declaring unwillingness to marry, knowing that it involves subjugation.

Another Dutch text, E. J. Potgieter's novella Marie, illustrates another aspect of self-conscious femininity and situates it within the nature-civilization opposition which permeated both scientific and novelistic writings of the late nineteenth and early twentieth centuries (Bud and Shiach 4). Referring to Marie, Du Toit discusses tomboys whom she defines as girls who have a "seungeaardheid [...] wat tog maar'n natuurlike liefde tot vryheid beteken" (the nature of a boy [...] which means a natural love for freedom") (72). As her argument goes, girls' nature is often stifled by social conventions, "dwang der beschaving" (compulsion of civilization) (71), which imposes passivity and obedience. Then she goes on to add a quote from George Meredith's Diana of the Crossways, showing the same model of unrestrained femininity in English novels. In this way, Du Toit stresses that being active is a natural feminine quality: "what Nature originally decreed, men are but beginning to see, that women are fitted to most of the avenues open to energy, and by their entering upon active life, they will no longer be open to the accusation $[\ldots]$ of being narrow and craven" (78).

It is worth noting that Du Toit's effort to introduce transnational feminism among Afrikaans women by referring to the Dutch culture is not the first such attempt. The prominent Dutch suffragist, Aletta Jacobs, president of the Dutch Vereeniging voor Vrouwenkiesrecht, visited South Africa during her 16-month long female suffrage world tour. From mid-August to late October 1911, at several meetings, she addressed Afrikaans-speaking audiences to emphasize the idea of their shared Dutch heritage. As she reports in her Reisbrieven uit Afrika en Azië (1913), her speeches were usually enthusiastically received. This should not surprise since the audience consisted of those middle-class women who were already in favour of female franchise. Jacobs does not mention any instances in which she manages to convert sceptics.

\section{References to the discourse of natural sciences}

Utilizing the concept of natural disposition, Du Toit moves freely between the discourse of prose fiction and the discourse of science. This is particularly evident in the chapter "Is die onderskeid so groot?" (Is the difference so big?) in which Du Toit addresses the differences between the sexes from a scientific perspective. She claims that her argument is based on "n noukeurige studie van die autoriteite" (a meticulous study of authorities) (55), but precedes her discussion with an excerpt from a novel by George Meredith, The Tragic Comedians (1881): "the choicest women are those who yield not a feather of their womanliness for some amount of manlike strength" (Marie du Toit 55).

The architextuality of Vrou en feminist lies in Du Toit's attempt to emulate the discourse of the authors she refers to, such as Elizabeth Robbins, Jean Finot, and Olive Schreiner, who presented the women's issue as a ma- 
ny-sided problem beyond the suffrage struggle. Du Toit adopts an anthropological perspective and lists, as per Finot and Schreiner, factors determining differences between men and women, such as material conditions, lifestyle, physical exercise, climate, and food (58-60). In this way her argument follows the late nineteenth and early twentieth centuries positivist approach with its focus on observable data. She refers to research on the relationships between the brain structure and intellect and concludes that:

[d] ie meeste skrywers wat ons teengekom het meen dat juis daar geen onderskeid is tussen man en vrou—veel meer verskeidenheid is te vinde deur een ras met'n ander te vergelyk ook in dese.

most writers whom we came across claim that in this very aspect there is no difference between a man and a womanmuch more variety can be found when comparing one race with another in this respect. (64)

Then she goes on to provide a list of medical doctors in favour of the claim that differences between a male and a female brain are negligible. She mentions such names as A. T. Scofield, Julius Bernsteinand, Havelock Ellis (author of Man and Woman, 1894), and concludes the enumeration by referring to the statement of Schofield:

Schofield gee b.v. aan dat Prof. A. Kirkhoff'Die Akademische Frau', 1897, bymekaar gebring het uit die opienies van oor die honderd vernaamste Duitse professore omtrent die bekwaamheid van vrouens in intellektuele wetenskap, en die uitslag is gepubliseer in'n boekdeel van 400 bladsye.

Schofield mentions, for example, that Prof. A. Kirkhoff, in 'The Academic Woman', 1897, collected opinions of more than a hundred prominent German professors as regards the competence of women in intellectual science, and published the result in a book chapter 400 pages long. (65)

Finally, Du Toit mentions distinguished women scientists, such as Madame du Chatelet, who in 1740 translated into French and provided commentary on Newton's Principles of Natural Philosophy (1687), and Madame Curie who discovered radium (66). Stressing that these women are only selected examples from a longer list and not exceptions or "abnormal" (67) women, she again debunks the argument of the alleged natural female inclination towards home tasks.

The scholarly diction that she emulates is marked by the drawbacks of then-popular Eurocentric Social Darwinism (see also Krebs (129) on Olive Schreiner and Jansen (107) on Aletta Jacobs). The inclusion of the racial argument betrays her adherence to the discourse that justifies the white man's superiority. Du Toit's racist thought can also be observed when she discusses the franchise system in the Cape Province which allowed certain non-white men to vote while excluding white women. Emphasizing the injustice done to women, she points to the inconsequence of the claim that women are ignorant of politics, noting that "(daar) nie gevra word of' $n$ bruin jong weet wat in die politieke wereld aangaan niet" (nobody asks if a coloured boy knows what is happening in the world of politics) (121). Expressing her indignation at women being treated worse than 'coloured' people, as they were called at the time, she concludes:

Vrouens is dus minder bekwaam om 'n stem uit te bring as gekleurdes, hulle (die vroue) word dan ook in dieselfde klas gesit as minderjarige, idiote, en misdadigers—die kannie stem nie-'ngrote eer, voorwadr!

Women are thus less capable of voting than coloureds, they (the women) are placed in the same class as minors, idiots, and criminals—who cannot vote-a great honour, indeed! (121)

The issue of miscegenation also serves to support her demand for the equality of men and women in the face of law. Arguing that white men should also be punished for intimate relationships with black women, she subscribes to the belief in the necessity of preserving racial purity (48).

Elsewhere, however, she refers to the writings of the anti-racist activist Jean Finot and compares the emancipation of women to the emancipation of slaves, arguing that sex prejudice is equivalent to racial prejudice (11). 
She extends the parallel to stress that women are practically a possession of men and as long as men take proper care of them, they should be content:

Onder die argumente teen hulle vrystelling is dit so opvallend dat die beskouinge en verontskuldiginge altyd van die baas se kant gesien is: hoe goed hy die slaaf behandel; hy bevestig hoe tevrede die slaaf is, dat hy die slaaf van al die nodige voorsien, ens. Maar [...] die vernaamste is tog: hoe voel die slaaf daaromtrent?

It is remarkable that as the arguments against their liberation the observations and excuses are always made from the perspective of the master: how good he treats the slave; he confirms how content the slave is, that he provided the slave with all that is necessary, etc. But [...] the main point is rather: how does the slave feel about it? (12)

The inability to see a contradiction in advocating for the emancipation of white women at the cost of non-whites was, however, typical of her era's progressive European intellectuals and proponents of female suffrage (see also Drwal 10-1). In the South African context, however, denying non-whites political rights was directly linked with growing Afrikaner nationalism. The fear of miscegenation, of "racial contamination" (Van der Westhuizen 34), juxtaposed with "a collective 'inferiority syndrome' and 'feeling of humiliation"' (27) after the loss of the AngloBoer War, led to the Afrikaners' need to assert themselves as equal-by virtue of their whiteness—but also distinct from the white English South Africans. As it turned out, this distinctiveness, defined as ethnicity (29), formed a stronger identification basis for Afrikaner women than the transnational gender-based emancipation struggle.

\section{References to theological writings}

The argument of natural inclination according to which women who want to vote are considered "unnatural" ("onnatuurlik") (Marie du Toit 208) was also employed by the discourse of theology. When commenting on the role of church teachings in perpetuating the inferior position of women in the family, Du Toit becomes sarcastic. Hinting at the supposedly reverent treatment that the woman receives as a wife, she observes:

aan die man behoort die vrou, die slaaf, die os en die muil, en dit wordt dan haar ere-posisie genoem!

to the man belongs the woman, the slave, the ox and the mule, and this is called her honourable position! (139)

In the same sarcastic tone, she exclaims: " $n$ Pakkameel-ereposisie voorwadr!" (a beast of burden (literally: a load-carrying-camel) position of honour indeed!") (139).

The repetitive use of "ere-posisie" (honourable position) seems to be an allusion to Abraham Kuyper's Decerepositie der vrouw (The Honourable Position of the Woman, 1914), a book in which the Dutch theologian and politician expounded why women should not vote. An Orthodox Calvinist, Kuyper based his argument on the Bible as presenting directives concerning the natural social order. Kuyper found devoted followers in a group of ministers who studied at the theological school in Potchefstroom, among them Jacob Daniël du Toit, called Totius, and Willem Postma, the author of Die boerevrouw, moeder van haar volk, in which he presents the volksmoeder ideal as the model of Afrikaner femininity (Giliomee 269). ${ }^{4}$ Even though Du Toit does not mention Kuyper's name in her book, the use of the very same vocabulary that he used allows us to assume that this is a metatextual reference, and that she is framing her commentary and polemics within his pattern of thought (Landman 345).

Similar references to Kuyper's writings can be found in Du Toit's attack on the church for propagating female subordination. Writing that "in die huisgesin is die vrou die mindere; sy is dus nie 'n persoonlikheid of indiwidu nie" (in a family the wife is the less important one; she is therefore not a personality or individual), Du Toit (38) seems to be alluding to Kuyper's claim that:

[h] uisgezinnen, [...] waarin de vrouw numero én geworden is en manlief de ondergeschikte speelt, zijn zondig saamgestelde gezinnen.

families $[\ldots]$ where the woman has become number one and the man plays the subjugated part, are sinfully composed families. (Kuyper 64)

The publication of Vrou en feminist needs to be situated in the context of Du Toit's father and brother's political activism. In 1920, Totius participated in a commission called by the Synod of the Reformed Churches (Synode van die Gereformeerde Kerke) to act as an advisory body to the parliament on the issue of female franchise. The commission ruled against granting women the right to vote on the grounds that it would be against the Chris- 
tian character of the Afrikaner nation (Landman 338-9). Therefore, Du Toit refers also to the official organ of the Reformed Church (139-41) that listed the reasons for the discarding of the female franchise proposal which echo Kuyper's views. The ideals of the French Revolution, which give individuals the right to decide their own lot, are presented as harmful to society's "organiese opbou" (organic structure) (140) that is designed by God (see Kuyper 11-3). Within this organism, women and men occupy naturally predestined positions and a woman who dares to act in the public sphere trespasses: "sy sal daar 'in oneer geraak"' (she will fall into disrepute) (Marie du Toit 141). Precisely the same claim can also be found in Kuyper's De eerepositie:

Wat in de natuur der vrouw het schoonst uitkomt, richt zich op het particuliere, wat den man uitnemendst siert, hoort bij het publieke leven. [...] Devrouw die, [...] den man wil nabootsen, verheft zich niet, maar daalt op de maatschappelijke ladder.

What is the most beautiful in the nature of the woman is directed towards the particular, what the man adorns most excellently belongs to the public life $[\ldots]$ The woman $[\ldots]$ who wants to imitate the man does not elevate herself but sinks on the social ladder. (Kuyper 164-65)

Pointing to the fact that the Church allows widows to act as the head of a family (Marie du Toit 14l, see Kuyper 58), Du Toit exposes the faults in this logic.

Furthermore, Du Toit demonstrates her knowledge of theological writings which contradict the dominant interpretations of the Bible. Engaging in a theological dispute, she quotes (in her Afrikaans translation) passages from Philip Mauro, an American author and lawyer (Marie du Toit 90-2). With excerpts from his The "Wretched Man" and His Deliverance (1910) she refutes the claim that the woman is the source of the original sin and concludes: "Die hele Bybel word erg eensydig en soms baie inkonsekwent teen ons aangehaal" (The whole Bible is quoted against us in a highly biased and sometimes very inconsequent way) (92).

\section{Commenting on the women's issue in English and Afrikaans press}

Du Toit looks up to the Europe of her time as the model for South Africa. She is up to date with the latest developments in Germany, Switzerland, and England - thanks to reading progressive press. Emphasizing that women's organizations and their press organs play a crucial role in furthering women's emancipation, she expresses her contentment that a new magazine, Time and Tide, has recently been established in England (42). Discussing the growing presence of women in new public spheres, performing equally well in professional jobs, Du Toit refers to an article in the March 1921 issue of Woman's Outlook, the Women's Enfranchisement Association of the Union of South Africa (WEAU) official magazine, in which women are praised for their efficiency and competence as members of the jury in courts in London (15).

The WEAU published contributions in both English and Afrikaans in its official publication The Woman's Outlook (1912-22) and subsequently in The Flashlight (1927-30) (Scully 74). Johanna Brandt, the author of Die Kappiekommando (1913), a popular Anglo-Boer War account based on her wartime activities as a spy, wrote for The Woman's Outlook. In her articles, she advocated female franchise because of women's responsibility as mothers of future generations. Presenting the woman as "de moeder van de staatsman" (the mother of the statesman) (Brandt 13) meant that middle-class women internalized the patriarchal nationalist volksmoeder discourse and adapted it in such a way as to legitimize suffrage as a duty towards the nation (Vincent 2). Nevertheless, most rural Afrikaner women were, if not sceptical of the idea of female suffrage, indifferent or simply unaware of it (Kruger 182-3). To overcome this attitude and to attract them to the movement, the WEAU issued recommendations to its activists to agitate by appealing to their duty as mothers of the nation (180).

Du Toit, however, protests reducing Afrikaner women to volksmoeders. She opposes women being defined by their duties to their family and people (117), just as she opposes their being described as parasites (125), reduced to the reproductive functions of their bodies-here she concurs with Schreiner's Woman and Labour. She envisions Afrikaans women as members of a transnational movement, and critically notes that the image of womanhood presented by local Dutch-Afrikaans press "is om enige feminist [sic] te laat wanhoop" (would make any feminist despair) (39). She goes on to accuse authors writing for these magazines of "verdraaiing van feite, vergesogte beskuldiginge of halwe waarheden" (bending facts, far-fetched accusations or half-truths) (39) in order to suppress the women's movement in South Africa.

Commenting on women's activism in South Africa, she admits that women who fight for franchise are predominantly English-speaking. She observes with satisfaction, however, that the English publication Woman's 
Outlook is active in South Africa and hopes that it will get more subscribers. She furthermore mentions that the WEAU has thirty-four branches in the Union and an association in Rhodesia (118). Yet, she points to Afrikaans women's indifference and ignorance of feminism and its worldwide dimension. This lack of gender solidarity between Afrikaans and English women is, she believes, the major obstacle to female emancipation (24). Regretfully, she reports that

Afrikaanse vrouens is [...] met weinige uitsonderings, baie lou en lusteloos teenoor so'n belangrike saak.

Afrikaans women are [...] with few exceptions, very lukewarm and apathetic about such an important issue. (116).

Mentioning forms of Afrikaans women's involvement in politics, such as membership of the Vroue Nasionale Party and Vroue Suid Afrikaanse Party, she emphasizes that these organizations are mostly concerned with the Nationalist Party interest and not with the interest of women and their right to vote (117).

\section{Reception of Vrou en feminist in South African press}

Brink (281), Pretorius (10), and Van Beek and Van Niekerk (536) unanimously accentuate that Vrou en feminist was not widely read at the time of its publication. However, it did not go unnoticed and received some reviews in both Afrikaans and English women's press which suggested that the book is a valuable contribution to the debate about women's social and political position.

It needs to be noted that the reviews did appear in the most widely read Afrikaans women's magazines, such as Die Boerevrou or Die Huisgenoot, but no reader's letters concerning the book were printed. The responses of Afrikaans critics were generally ambiguous. A rather sceptical review appeared in the September 1921 issue of the conservative magazine Die Boerevrou (Anon, "Die Boerevrou se Boekrak" 9). The reviewer encourages the readers to get acquainted with Vrou en feminist and praises the author's erudition, but also observes that Du Toit describes the underprivileged position of women in England, which is completely irrelevant for a South African reader. The review stresses that the South African legal system, based on Roman-Dutch law, is more favourable to women and adds that even Englishwomen's legal position has recently improved, and that Du Toit relies on outdated information. This short discussion of the book closes with a remark that Afrikaner women have always been held in high esteem by their people and that in the nearest future there will hopefully be more publications truthfully reflecting social reality and the women's issue in South Africa. The contributor expresses regret that "een van ons eerste boeke oor die belangrijke onderwerp miskien'n verkeerde indruk kan maak" (one of our first books about this important topic could perhaps give a wrong impression) (9). Die Huisgenoot of November 1921, in contrast, presents the book in a much more positive light. It expresses admiration for the eloquent and clear style, and recommends reading it, because it may have a positive result, namely:

[om] ons tot dink aan [te] spoor, sodat ons dit graag sou wou sien in die hande van elke leseres van Die Huisgenoot, om vir die eerste keer of opnuut kennis te neem van die belangrike vraagstukke hierin bespreek.

[to] encourage us to think, therefore we would like to see it in the hands of every woman reader of Die Huisgenoot, so for the first time or again she can learn about the important issues which are discussed therein. (Van Niekerk 275)

The Woman's Outlook informs readers that the WEAU wished that the book would help to bridge the gap between Afrikaans and English-speaking women, so they may engage in a joint emancipation struggle. An article in the November 1921 issue reports that "[1] etters have been sent to the leading Dutch papers advising people to read the book" (Anon., "Vrou en feminist" 10). Moreover, the organization purchased fifty copies of the Vrou en feminist and planned to distribute them among the Afrikaans women who would then "bring it to the notice of their friends" (10). No information can be found as to whether the action was successful.

\section{Conclusion}

Vrou en feminist originated as an attempt to introduce the Afrikaner readership to European and North American feminism. Writing in Afrikaans about the woman question, an allegedly British and alien phenomenon, Du Toit wanted to overcome prejudice and incorporate transnational thought into the local South African context. To legitimize her unpopular views, she relied on recognized discourses and authorities. Employing a multitude of 
voices to support her argument, she created a heteroglot text with a subversive potential serving to criticize the conservative local social order and to offer an alternative transnational image of femininity.

The book is a literary document presenting a particular facet of Afrikaans literary history. It illustrates how progressive discourses of science (natural sciences, sociology, anthropology), which served a transnational modernizing trend of the late nineteenth and early twentieth centuries, operated in an Afrikaans text. The list of consulted and recommended literature and numerous intertextual and paratextual references give an insight into what a progressive South African intellectual woman read and how she aspired to a transnational imagined community of feminists. Thus, the book documents a history of readership and circulation of texts between Europe and South Africa, and in particular reflects on the impact of English texts-which form the vast majority of sources cited-but also of literature in Dutch. As a source of cultural identification, the Dutch cultural legacy could have potentially served to balance the prejudice against feminism as a British concept that is hostile to the Afrikaner worldview. The text testifies to the simultaneous presence in South Africa of both the conservative political and theological thought of Abraham Kuyper, and of progressive feminism as manifest in novels read and recommended by Du Toit. It is worth stressing that she chose Dutch novels (by Bosboom-Toussaint and Potgieter) to discuss everyday issues, since they could most effectively reflect and shape mentality and offer role models with which her readers could identify. Furthermore, a reference to working-class women emancipation at the intersection with socialism in Roland Holst's theoretical writings presents the Netherlands as a progressive cultural and social centre.

The press reviews show, however, that Du Toit's book did not meet with a truly receptive public. Despite interest in the new approach and appreciation for her erudition, the reactions show that the references to Dutch progressive literature were insufficient to overcome the negative image of feminism as a British concept. The reviewers point to excessive references to England and argue its situation is irrelevant to the South African context. The transnational idea that the woman becomes an agent voting for her own sake lost to the local view that women need franchise as volksmoeders responsible for their nation - and are thus responsible for supporting Afrikaner men in the pursuit of a nation-building project.

\section{Acknowledgements}

This research was funded by the Polish National Science Centre (NCN) SONATA 14 grant (grant no. 2018/31/D/HS2/00131:

"White South African New Women and cultural mobility in the first half of the 20th century").

\section{Notes}

1. Greenblatt proposes that the point of departure for cultural mobility studies should be movement - understood both literally and figuratively - which leads to cultural exchage. He suggests identifying contact zones that enable exchange: circulation of texts (e.g. translations), physical movement of people (travel, migration), and personal contact between individuals (as recorded in letters and diaries). He also points to the importance of looking into "the tension between individual agency and structural constraint" (251).

2. Genette distinguishes five ways in which transtextual relationships are formed. This is done by means of intertextuality, paratextuality, metatextuality, hypertextuality, and architextuality. Hypertextuality, which is a form of reference including, for example, parody and pastiche, does not appear in du Toit's text, therefore I list only four types which are discussed in the article.

3. The poem was written to honour Betty Zane, a heroine from the American Revolutionary War. Risking her life, Zane managed to provide ammunition to Fort Henry in West Virginia under British attack in 1777.

4. Postma's book (published under the pseudonym Dr. Okulis) and Die Vrou in die Geskiedenis van die Hollands-Afrikaanse Volk (1921) by Eric Stockenström were two highly influential publications that perpetuated the volksmoeder image.

\section{Works Cited}

Anon. "De vrouw en arbeid.” Evolutie: Veertiendaagsch Blad voor de Vrouw, 24 May 1911, pp. 28-30.

Anon. “Die Boerevrou se Boekrak.” Die Boerevrou, Sep. 1921, p. 9.

Anon. "Vrou en feminist." The Woman's Outlook, Nov. 1921, p. 10.

Anderson, Benedict. Imagined Communities: Reflections on the Origin and Spread of Nationalism. Verso, 1983.

Bakhtin, Mikhail. The Dialogic Imagination. Four Essays. Trans. Caryl Emerson \& Michael Holquist. Austin U of Texas P, 1981.

Berger, Iris. Threads of Solidarity: Women in South African Industry, 1900-1980. Indiana U P, 1992.

Brandt, Johanna. The Woman's Outlook, Feb. 1914, p. 13.

Brink, Elsabé. "Man-Made Women: Gender, Class and the Ideology of the Volksmoeder." Women and Gender in Southern Africa to 1945, edited by Cherryl Walker. David Philip, 1990, pp. 273-92.

Brittain, Vera. Testament of Youth. An Autobiographical Study of the Years 1900-1925. Victor Gollancz, 1933.

Bud, Robert \& Morag Shiach. "Introduction. Being Modern." Being Modern. The Cultural Impact of Science in the Early Twentieth Century, edited by Robert Bud, et al. UCL, 2018, pp. 1-20. 
Drwal, Małgorzata. "The Feminism of Olive Schreiner and the Feminism of Aletta Jacobs: The Reception of Schreiner's Woman and Labour in the Netherlands”. Dutch Crossing 2019. DOI: https://doi.org/10.1080/03096564.2019.1693200.

Du Toit, Marie. Vrou en feminist. Of iets oor die vrouevraagstuk. Nasionale Pers, 1921.

Du Toit, Marijke. "Women, Welfare and the Nurturing of Afrikaner Nationalism: A Social History of Afrikaanse Christelike Vroue Vereniging, c. 1870-1939." Diss. U of Cape Town, 1996. http://hdl.handle.net/11427/26212.

Genette, Gérard. Palimpsests: Literature in the Second Degree. Trans. Channa Newman \& Claude Doubinsky. U of Nebraska P, 1997. . Paratexts. Thresholds of Interpretation. Cambridge U P, 2001

Giliomee, Hermann. The Afrikaners: Biography of a People. Hurst, 2003.

Greenblatt, Stephen J. Cultural Mobility: A Manifesto. Cambridge U P, 2009.

Jacobs, Aletta. Reisbrieven Uit Afrika En Azië: Benevens Eenige Brieven Uit Zweden En Noorwegen. Boekdrukkerij W. Hilarius Wzn, 1915.

Jansen, Ena. "The Discourse of Difference in Reisbrieven uit Afrika en Azië [1913] by Dr Aletta Jacobs: A Dutch Feminist's Perspective on South Africa and the Dutch East Indies." Journal of Literary Studies vol. 14, no. 1-2, 1998, pp. 102-15. DOI: https://doi.org/10.1080/02564719808530191.

Krebs, Paula M. Gender, Race and Writing of Empire. Public Discourse and the Boer War. Cambridge U P, 1999.

Kruger, Lou-Marie. "Gender, Community and Identity: Women and Afrikaner Nationalism in the Volksmoeder Discourse of Die Boerevrou, 1919-1931." M. A. thesis. U of Cape Town, 1991. http://hdl.handle.net/11427/17313.

Kuyper, Abraham. De eerepositie dervrouw. J. H. Kok, 1914.

Landman, Christina. "Abraham Kuyper en Marie du Toit oor Vrouestemreg." In die Skriflig vol. 27, no. 3, 1993, pp. 337-48. DOI: https://doi.org/10.4102/ids.v27i3.1465.

Pretorius, Engela. "Communicating Feminism to the Community: The Continuing Relevance of Feminist Fifty Years after 9 August 1956." Communitas vol. 1l, 2006, pp. 1-20. http://journals.ufs.ac.za/index.php/com/article/view/906.

Schreiner, Olive. Woman and Labour. Fisher Unwin, 1911.

Scully, Pamela. "White Maternity and Black Infancy: The Rhetoric of Race in the South African Women's Suffrage Movement, 1895-1930." Women's Suffrage in the British Empire: Citizenship, Nation and Race, edited by Ian Christopher Fletcher, Philippa Levine \& Laura E. Nym Mayhall. Routledge, 2002, pp. 68-84.

Swart, Sandra \& Lize-Marié van der Watt. "Taaltriomf of Taalverdriet?': An Aspect of the Roles of Eugene Marais and Gustav Preller in the Second Language Movement, circa 1905-1927". Historia vol. 53, no. 2, 2008, pp. 126-50. http://www. scielo.org.za/scielo.php?script=sci arttext\&epid=S0018-229X2008000200007\& lng=en\&etlng.

Van Beek, Pieta \& Annemarié van Niekerk. My Mother's Mother's Mother: South African Women's Writing from 17th Century Dutch to Contemporary Afrikaans. Leiden U P, 2019.

Van der Westhuizen, Christi. Sitting Pretty. White Afrikaans Women in Postapartheid South Africa. U of KwaZulu-Natal P, 2017.

Van Niekerk, Lydia. "n Belangrike Boek. Vrou en feminist, of iets oor die Vrouevraagstuk. Deur M. du Toit." Die Huisgenoot, November 1921, pp. 275-6.

Venuti, Lawrence. "Translation, Community, Utopia." The Translation Studies Reader, edited by Lawrence Venuti. Routledge, 2004, pp. 468-88.

Vincent, Louise. "A Cake of Soap: The Volksmoeder Ideology and Afrikaner Women's Campaign for the Vote." The International Journal of African Historical Studies vol. 32, no. 1, 1999, pp. 1-17. DOI: https://doi.org/10.2307/220803.

Werner, Michael \&\& Bénédicte Zimmermann. "Beyond Comparison: Histoire Croisée and the Challenge of Reflexivity." History and Theory vol. 45, no. 1, 2006, pp. 30-50. DOI: https://doi.org/10.1111/j.1468-2303.2006.00347.x. 